\title{
Use of statistical tools in hydrogeological research
}

\author{
Anna Mika \\ AGH University of Science and Technology; al. A. Mickiewicza 30, 30-059 Krakow, Poland; e-mail: annamika@agh.edu.pl \\ (C) 2016 Authors. This is an open access publication, which can be used, distributed and reproduced in any medium according \\ to the Creative Commons CC-BY 4.0 License requiring that the original work has been properly cited.
}

Marcus Cicero said "Any man can make mistakes, but only an idiot persists in his error". In this paper, some statistical tools are presented, which give scientists an opportunity to reduce or eliminate their mistakes and could help to assess results of high quality and their presentation.

In hydrogeology and hydrogeochemistry every stage of research could cause serious errors. IBM SPSS software is a modular system designated to the data analysis or visual presentation of the results. SPSS gives a lot of possibilities to illustrate the results of chemical analysis using different plots, which can show a dependence of results from sampling points or time changes of ion concentrations. Another software, GWSDAT, is freeware, a supplement to Microsoft Excel, based on $\mathrm{R}$ language. This software provides trend assessment (Jones \& Spence 2013) and visual presentation of results e.g. as a concentration map.

The basic statistical method to evaluate the quality of the analysis is an error based on the ions balance. The values of this error can be shown on a histogram with references line (pictured the threshold value include in ruling standards). A chemical analysis result could also be illustrated on a box-and-whisker plot. Then we can show which concentrations diverge values or are higher than parametric value assigned by the regulations.

The second method for quality control of the obtained analysis results is a control chart. This diagram bases on recording results of measurements of the analysed parameters e.g. concentrations of ions (Szczepańska \& Kmiecik 2005). Control limit lines (Upper Control Limit and Lower Control Limit) are usually determined as three standard deviations from the mean value. Control limit-crossing is named as a single signal (S).
The presence of a single signal on the control chart could be a basis to question the accuracy of analysis (Szczepańska \& Kmiecik 2005).

To get more reliable chemical analysis results, they should be reported with their uncertainty. The uncertainty of measurement is a parameter that characterizes the analytical method and specify the confidence interval of true value. It's an interval in which "the real" value should be with specified probability. The total uncertainty is calculated on the basis of the uncertainty of all parameters and actions/analytical process stages, which have an impact on the result of analysis e.g. sampling, methodology, transport (Kmiecik 2011). The uncertainty enhances the reliability of the results and helps to make correct decisions e.g. during groundwater chemical status assessment.

The statistical tools are helpful in the interpretation of the results, especially when they are related to the current legislation. Meanwhile, the plots and maps are useful in the presentation of the results to people, who are not related to hydrogeology (e.g. investors).

\section{REFERENCES}

Jones W. \& Spence M., 2013. GroundWater Spatio-Temporal Data Analysis Tool (GWSDAT Version 2.0 User Manual, Shell Global Solution (UK). [on-line:] http://www.api. org/ /media/files/ehs/clean_water/gw_other/gwsdat_ v2_1/gwsdat\%20user\%20manual\%20v21.pdf?la=en [access: January 2016].

Kmiecik E., 2011. Metodyczne aspekty oceny stanu chemicznego wód podziemnych. Wydawnictwa AGH, Kraków.

Szczepańska J. \& Kmiecik E., 2005. Ocena stanu chemicznego wód podziemnych w oparciu o wyniki badań monitoringowych. Uczelniane Wydawnictwa Naukowo-Dydaktyczne AGH, Kraków. 